\title{
Police's Role to Prevent Criminal Act of Rape-Murder (Study Case of Police Labuhan Ruku Talawi Sub-District, Batubara District, North Sumatera)
}

\author{
Rizkan Zulyadi \\ Universitas Medan Area, Medan, Indonesia \\ rizkan@staff.uma.ac.id
}

\section{Abstract}

This study aims to analyze how the factors causing the occurrence of criminal act of rape-murder, what is the role of investigators in uncovering criminal act of rape-murder police of Batubara District, What are the obstacles faced by investigators in uncovering rape-murder in Police Labuhan Ruku Talawi. The research method uses in this study is Analytical Descriptive. In this case the researchers directly conducted research into Police Labuhan Ruku Talawi, Batubara Sub-District, North Sumatera. The results shows obtained are criminal acts of murder can occur due to factors that support the occurrence of these killings which can be caused through many things including through, conditions, circumstances and so forth that give room for the occurrence of these things. The role of the police investigator is to uncover the occurrence of a criminal act of murder through a series of acts of search and examination of matters relating to the murder case. Obstacles faced by investigators in uncovering murder cases include the lack of equipment and facilities and also the absence of witnesses that complicate the examination process.
Keywords

police; investigation; crime; rape

\section{Introduction}

Initially the term "police" was derived from the Greek "Politeia" which means the entire city government. As it is known that in BC before BC, in Greece many cities called "Polis". At that time the meaning of the police was related to all government affairs or in other words the police were for government affairs. This understanding of the police always changes the development of the nature and form of the state and the government.

The National Police of the Republic of Indonesia or often in short with the National Police in relation to the government is one of the functions of government in the field of maintaining security and public order, law enforcement, protection, protection, and service to the community. Aiming to realize domestic security which includes maintaining the security and order of the people, orderly and upholding the law, implementation of protection, protection, and community services, as well as the creation of public peace by upholding human rights, this is contained in Article 4 of Law Number 2 Year 2002 about Police Republic of Indonesia.

The police or the police are the front guard in criminal law enforcement so it is not excessive if the police are said to be living criminal law. The police or police aims to realize domestic security which includes maintaining the security and order of the people, orderly and upholding the law, protecting, protecting and providing services to the community and maintaining the peace of society by upholding human rights. 
The police as government officials, the organization is within the scope of the Government. In other words the Police organization is part of the Government Organization. In terms of language, a police organ is a tool or body that carries out police duties. So that these tools can be coordinated, and achieve the desired goals, then given the division of work and accommodated in a container that is usually called the organization. Thus, its existence, growth and development, its shape and structure are determined by the vision of the Government concerned for the implementation of its Police duties. Around the world the Police Organization is different. There are those who are in charge of the Ministry of Home Affairs, there are those who are under the Ministry of Justice, there are those who are under the control of the Prime Minister, the Vice President, is controlled by the President himself, and there are even those who are independent departments.

Crimes especially killings, people used to kill in a simple way so that it is easily revealed by the police. But now there is a murder incident in a different and quite sadistic way, namely by way of mutilation. This is done with the aim to trick the officers, disguise the identity of the victim so that it is difficult to find clues about the identity of the victim, and eliminate traces of the victims such as cutting victims' body parts into several parts, such as the head, body and other body parts, which is then discarded separately. Mutilation is the cutting or destruction of a corpse, not infrequently having a motive for sexual crime, where the victim's body is not infrequently damaged, cut into several parts.

Rape is a criminal act of a sexual nature that occurs when a human being forces another human to have sexual relations in the form of vaginal penetration with a penis, by force or by force. In the big Indonesian dictionary, rape comes from the word rape which means to violate or violate with violence. While rape is defined as a process, method, act of rape or violation by force. Article 285 of the Criminal Code requires that there be co-sexual relations that are not his wife accompanied by threats of violence. Rape is characterized by the penetration of the penis into the vaginal opening during sex accompanied by threats and physical violence against the victim by the perpetrator.

Murder is an act that can cause the loss of another person's life. In the Criminal Code (KUHP), the crime of life is regulated in Book II Titel XIX (Article 338 to Article 350). The meaning of life itself is almost the same as the meaning of the soul. The word soul has several meanings, including; the giver of life, soul and spirit (which makes man alive). While the word soul means human spirit and all human life. Thus the crime against a life can be interpreted as a crime that involves a person's life.

KUHP Article 338 which reads as follows: Anyone who intentionally takes another person's life, is threatened with murder for a maximum imprisonment of 15 years. Based on the description above the writing has a connection to find out this matter then raised the Title "The Role of the Police in the Case of the Criminal Investigation Investigation with Rape" (Case Study of Labuhan Ruku Police Station in Talawi Sub-District: Batubara District, North Sumatra).

\section{Review of Literature}

\subsection{Criminal Acts}

The term criminal offense is a translation of "strafbaar feit" acts that are prohibited by a prohibited legal rule by which is accompanied by threats (sanctions) in the form of certain penalties, for anyone who violates the prohibition. The Criminal Law Code does not have an explanation of what exactly is meant by the strafbaar feit itself. Crime is usually equated with delik, which comes from the Latin word delictum. Delik is listed in the Big Indonesian 
Dictionary as follows: "Delik is an act that can be subject to punishment because it is a violation of criminal law".

The definition of a criminal offense is an act that is not only formulated by the Criminal Code, 17 the term crime as the translation of strafbaarfeit shows the understanding of the movements of a person's behavior. According to Wirjono Prodjodikoro, a criminal act means an act in which the culprit may be subject to a criminal sentence. 18 There are also things that someone does not do, but by not doing so, he has committed a crime. Regarding the obligation to do but not act, which in the law stipulates in Article 164 of the Criminal Code, the provisions in this article require someone to report to the authorities if a crime will occur, it turns out he did not report, then he may be subject to sanctions. As is known the term strafbaarfeit has been translated into Indonesian which gives rise to various meanings, for example it can be said as an act that can or may be punished, a criminal event, a criminal act, a criminal offense. Indonesian scholars term the straafbarfeit in different meanings, including Moeljatno using the term criminal acts, namely: "acts that are prohibited by a rule of law, which prohibitions are accompanied by the threat of certain criminal sanctions, for whom the ban is"

a. Types of Criminal Acts

Types of criminal acts consist of violations and crime. This division of criminal offenses has a material legal effect, which is as follows:

- The law does not make a difference between opzet and culpa in an offense

- Attempts on an offense cannot be punished.

- Participation in violations cannot be punished

- Violations committed by management or members of the board or commissioners can be punished if the violation occurs to their knowledge.

- In the violation, there is no provision that a confession is a condition for prosecution.

\subsection{Overview of Rape}

The word rape comes from the Latin rapere which means to steal, force, seize, or take away. In the past rape crimes were often carried out to obtain a wife and rape crimes not only in the form of sexual intercourse but all forms of assault involving genitals by means of violence and coercion by perpetrators against victims. The rape crime as regulated in Article 285 of the Criminal Code reads as follows: "Anyone who violently or threatens to force a woman who is not his wife to have intercourse with him, because of rape, has been sentenced to a maximum of twelve years in prison."

Rape is a criminal act of a sexual nature that occurs when a human being forces another human to have sexual relations in the form of vaginal penetration with a penis, by force or by force. In the big Indonesian dictionary, rape comes from the word rape which means to violate or violate with violence. While rape is defined as a process, method, act of rape or violation by force. The word rape comes from the Latin rapere which means to steal, force, seize, or take away.34 According to R. Sugandhi stated that: "Rape is a man who forces a person who is not his wife to have intercourse with him with the threat of violence, which in must the male genitals have entered into the female genitalia which then secretes sperm.

According to Wirjono Prodjodikoro, what is meant by rape is "A man who forces a woman who is not his wife to have intercourse with him, so that he cannot do it, so he is forced to have intercourse". In the past rape crimes were often carried out to obtain a wife and rape crimes not only in the form of sexual intercourse but all forms of assault involving genitals by means of violence and coercion by perpetrators against victims. The rape crime as stipulated in Article 285 of the Criminal Code which reads as follows: "Anyone who violently or threatens to force a woman who is not his wife to have intercourse with him, 
because of rape, is convicted with imprisonment for a maximum of twelve years". Article 285 of the Criminal Code requires that there be co-sexual relations that are not his wife accompanied by threats of violence. Rape is characterized by the penetration of the penis into the vaginal opening during sex accompanied by threats and physical violence against the victim by the perpetrator.

\subsection{Overview of Murder}

The crime of murder is a material crime or materiel delict, which is a criminal offense that can only be regarded as completed by the perpetrators with the emergence of prohibited or undesirable results by the law. Thus, one cannot speak of a murder crime, if the consequences of the death of another person have not yet arisen.

Therefore, the occurrence is the loss of another person's life, so it cannot be said that the death of the other person has not yet been realized. If the purpose of eliminating other people's lives is not realized then it can only be called an attempted murder.

Arrangements regarding criminal provisions concerning crimes aimed at people's lives, we can also know that the legislators have intended to make a distinction between the various crimes that people can commit against people's lives by committing these crimes in five types of crimes aimed at people's lives. , each of the following:

- Crimes in the form of eliminating the lives of others in a general sense, about crimes where the next lawmaker also still makes the difference between intentionally eliminating the lives of others who are not planned in advance that has been given the name of doodslag with intentionally eliminating the lives of others by premeditated he called the moord regulated in article 338 of the Criminal Code while the moord was regulated in article 340 of the Criminal Code.

- Crimes in the form of deliberate loss of life of a child who was just born by his own mother. Regarding this crime, the legislators still make a difference between intentionally eliminating the life of a child committed by their own mother who was carried out unplanned by deliberately eliminating the life of a child newly born by his own mother committed by premeditation, the type of crime mentioned first of all that by the legislators has been referred to as kinderdoodslag and regulated in article 341 of the Criminal Code, while the type of crime mentioned later is kindermoord and regulated in article 342 of the Criminal Code. 41

- A crime in the form of intentionally eliminates the life of a person at the request, which is firm and serious from the person himself, that is as stipulated in article 344 of the Criminal Code. 42

- Crimes in the form of intentions to encourage others to commit suicide or help others commit suicide as stipulated in article 345 of the Criminal Code

- Crimes in the form of intentional abortion of a woman's womb or cause a child who is in the womb to die. The abortion by the legislators has been referred to as afdrijving.

\subsection{Duties and Powers of the Indonesian National Police as Law Enforcement Agencies}

Understanding the police is also contained in the Law in Indonesia. The law that discusses the Indonesian National Police is contained in Law No. 2 of 2002 in Article 1 paragraph (1). In Law Number 2 of 2002 Article 1 paragraph (1) states that "Police are all matters relating to the functions and institutions of the police in accordance with statutory regulations; Members of the Republic of Indonesia National Police are civil servants of the Republic of Indonesia National Police. The function of the police as one of the functions of the state government in the field of maintaining security and public order, law enforcement, protectors, patronage and service to the community. Whereas a police institution is a 
government organ determined as an institution and given the authority to carry out its functions based on statutory regulations.

\subsection{The Role of the Police in Criminal Acts}

Law enforcement officers, which in the strict sense only mean the police but can also include prosecutors. However, in Indonesia it is usually expanded with Judges and there is a strong tendency to include law enforcement as well as lawyers. In this last broad sense, a translation of rechthandhaving, which means law enforcement can be used. Conceptually, the essence and meaning of law enforcement lies in the activity of harmonizing the values that are set out in the rules that are steady and manifest and the attitude of action as a series of translation of the final stage of values, to create, preserve and maintain peaceful social relations.

The role of the National Police according to Article 1 paragraph (5) of Law no. 2 of 2002 concerning the Indonesian National Police, namely:

"Security and public order is a dynamic condition of the community as one of the prerequisites for the implementation of the national development process which is marked by ensuring order and enforcement of the law and maintaining peace that contains the ability to foster and develop the potential and power of the community in preventing, preventing and overcoming all forms of violations of the law. and other forms of disturbances can disturb society".

\section{Research Methods}

This research uses Empirical Law research which is a legal research method that functions to look at the law in the real sense and examine how law works in the community. This is because this study aims to examine people in life relationships in the community, empirical legal research methods can be said as sociological legal research.

This study also uses descriptive analytical research methods, as stated by Soerjono Soekanto56, research that is descriptive analytical is intended to provide data that are as detailed as possible about humans, circumstances, or specific symptoms. The intention is to reinforce hypotheses, in order to strengthen old theories or within the framework of developing new theories. Descriptive analysis research aims to investigate in detail human activities and work, and the results of these studies can provide recommendations for future needs. The research was carried out at Police Labuhan Ruku Talawi, Batubara District, North Sumatera.

\section{Discussion}

\subsection{Cause of Rape-Murder in Labuhan Ruku}

The murder that occurred in Labuhan Ruku happened to a woman who was a native, the woman was known to have died after a crowd sought by residents around Labuhan Ruku, the initiative to find a murder victim was carried out because at that time the woman did not return home after dusk which should be has returned home and then by family may immediately notify people around to do a search. The discovery of the corpse also produced results after a long time around the area around the last woman was, the woman was in the river and was found naked with a state of face bruised and strangled marks that indicate that the woman was strangled to death.

Research shows that the occurrence of rape-murder criminal act after studying matters relating to the crime, it can be concluded that the murder occurred because the woman gave 
resistance when she was going to be raped, swiftly the suspect committed an act of strangulation that led to the loss of the woman's life, then seeing the woman died then to cover up his mistake the suspect removed the evidence and threw the victim's body in the river.

\subsection{Effectiveness of the Police in Uncovering Criminal Cases}

The obstacles affecting the effectiveness of the police encountered by investigators in the activities carried out by the identification unit to help the investigation are divided into 2 factors, namely:

- Internal Factors Employee factors have a very dominant role in processing crime scenes in order to gather evidence for further investigation. The ability of officers to identify is an important element in finding evidence, the ability of officers who lack knowledge of identification will have difficulty in finding evidence or even damage the traces of the perpetrators who should be able to make evidence. Equipment is also one of the most important factors in identifying. The completeness of the equipment for investigation also greatly supports the success of the investigator in gathering evidence, the limitations of the tool also affect the limitations of the evidence collected. Especially if the investigator is confronted with a crime scene that has been a long time, because the crime is only known after a long time.

- External Factors Lack of legal awareness and public concern about criminal acts and the investigation process at crime scenes in criminal cases, can cause difficulties for investigators in obtaining evidence. Enthusiastic community around the crime scene location can be a big threat, especially on the authenticity of the crime scene, this is because in general the public wants to witness what has happened, and without his knowledge can lead to loss of traces of the perpetrators and even damage to the latent fingerprints of the perpetrators due to being erased or piled up by the community when touch or move items that might be held by the perpetrators of crime.

\subsection{Factors causing the occurrence of Criminal Acts of Rape-Murder}

With regard to the results of the interview, it is known that there are a number of factors which are the basis of the killings where the suspect commits his actions and the actions are based on the following factors:

a. Condition

The act could occur due to the condition of the condition which at that time made it possible to carry out a crime, this was because the victim at that time was only doing his own activity, besides that the suspect accidentally saw the victim being alone without supervision being doing his activities then the thought arose to rape the victim before finally leading to murder.

b. Intention

The intention arises in the suspect due to seeing a woman alone besides that the conditions are quite possible to carry out the action, making the suspect have such an intention to rape.

c. Lack of supervision

The act of killing can occur due to lack of supervision from other people or families when the victim wants to carry out their duties. This provides an opportunity for the suspect to approach the victim and commit the act. 


\subsection{The Role of Investigators in Uncovering Murder Cases at Batubara Sub-District Police}

J. Tarigan assistant investigator from the interview explained that the Police / Investigator together with the Sabhara unit and the Criminal Investigation Unit both the Investigator / Investigation Unit immediately went to the scene because many cases were revealed from the results of the crime scene which was maximally carried out by officers when the crime scene was conducted.

J. Tarigan said that the role of the police must be in accordance with the provisions of existing legislation, as contained in Law No. 2 of 2002 concerning State Police as the legal basis for carrying out the duties and authorities of the police as follows:

Article 14

a. In carrying out the main tasks as referred to in Article 13, the National Police of the Republic of Indonesia is tasked with:

- Implementing arrangements, guarding, escorting and patrolling community and government activities as needed;

- Carry out all activities in ensuring the security, order and smooth traffic on the road;

- Fostering the community to increase community participation, community legal awareness and community adherence to laws and regulations;

- Participate in the development of national law;

- Maintaining order and ensuring public security;

- To coordinate, supervise and provide technical assistance to special police, civil servant investigators, and forms of self-help security;

- Investigate and investigate all criminal acts in accordance with the criminal procedure code and other laws and regulations;

- Carrying out police identification, police medicine, forensic laboratories and police psychology for the purpose of police work;

- Protect the safety of the body and soul, property, community and environment from disruption of order and / or disaster including providing assistance and assistance by upholding human rights;

- Serve the interests of community members temporarily before being handled by the agency and / or the authorities;

- Providing services to the community in accordance with their interests within the scope of police duties; and

- Carry out other tasks in accordance with statutory regulations.

b. The procedure for implementing the provisions referred to in paragraph (1) letter $f$ shall be further regulated by a Government Regulation.

\subsection{Obstacles faced by Investigators in uncovering Murder Cases}

There are several obstacles that affect the duties and functions of the Police in uncovering Murder cases including the following:

a. Facilities and Facilities in Law Enforcement Lack of facilities needed both in terms of medical and forensics in providing efforts in making light of a minimal murder case in certain regions as well as inafis parts that lack synergy in various police sectors and inadequate facilities to find and find traces suspect of murder which is still lacking in several police locations.

b. Community Community participation and control in some areas is still very low due to a sense of ignorance about the environment itself, although it is clearly seen directly in the act of drug abuse. This is due to the assumption that the Police will take their hands off 
and not provide security protection for the complainant. c. Lack of Witnesses Lack of attendance for witnesses who may be aware of criminal incidents makes it difficult for investigators to conduct an examination process in making light of a criminal case

\section{Conclusion}

The crime of murder can occur due to factors that support the occurrence of the act of murder which can be caused through many things including through, conditions, circumstances and so forth that gives room for the occurrence of these things. The role of the police investigator is to uncover the occurrence of a criminal act of murder through a series of acts of search and examination of matters relating to the murder case. The obstacles faced by investigators in uncovering murder cases include the lack of equipment and facilities and also the absence of witnesses which complicate the examination process.

\section{References}

Abdul Wahid dan Muhammad Irfan. 2001. Perlindungan Terhadap Korban Kekerasan Seksual. Bandung :PT. Refika Aditama.

Adami Chazawi. 2001. Kejahatan Terhadap Tubuh dan Nyawa. Jakarta :PT. Raja Grafindo Persada. Ahmad Ali. 2009. Menguak Teori Hukum (Legal Theory) dan Teori Peradilan (Judical Prudence). Jakarta: Kencana.

Andi Hamzah. 1985. Pengusutan Perkara Kriminal Melalui Sarana Teknik dan Sarana Hukum. Jakarta :Ghalia Indonesia.

Andi Hamzah. 1994. Asas-asas Hukum Pidana. Jakarta: Rineka Cipta.

Andi Hamzah. 2001.Bungan Rampai Hukum Pidana dan Acara Pidana. Jakarta:Ghalia Indonesia.

Andi Hamzah. 2006. Hukum Acara Pidana Indonesia, Edisi Revisi. Jakarta :Sinar Grafika. Atmasasmita,

Romli. 2005. Teori dan Kapita Selekta Kriminologi. Bandung :PT. Refika Aditama. Bambang Poernomo. 1981. Asas-asas Hukum Pidana. Jakarta :Ghalia Indonesia.

Tri Andrisman. 2007. Hukum Pidana (Asas-asas dan Dasar Aturan Umum Hukum Pidana Indonesi).Bandar Lampung :CV. Sinar Bakti.

Bambang Sunggono. 2011. Metodologi Penelitian 1997. Jogjakarta :Pusat Studi Wanita Universitas Gajah Mada.

Pudi Rahardi. 2014. Hukum Kepolisian. Surabaya :Laksbang Grafika.

R. Soesilo. 1980. Taktik dan Teknik Penyidikan Perkara Kriminil. Bogor :Politea.

S.R. Sianturi. 2002. Asas-asas Hukum Pidana di Indonesia dan Penerapan, Cet. 3, Jakarta : Storia Grafika. Sadjijono. 2001. Etika Kepolisian. Surabaya :Laksbang Mediatama.

Santoso, Topo. 1997. Seksualitas dan Pidana, Jakarta :In Hill.

Satjipto Raharjo. 2002. Polisi Sipil dalam Perubahan Sosial di Indonesia. Jakarta: Penerbit Buku Kompas.

Soerjono Soekanto. 1982. Kesadarandan Kepatuhan Hukum. Jakarta : Rajawali.

Soerjono Soekanto. 1986. Pengatar Penelitian Hukum. Jakarta :Universitas Indonesia.

Soerjono Soekanto. 2002. Sosiologi Suatu Pengantar. Jakarta :Rajawali Press.

Untung S. Rajab. 2003. Kedudukan dan Fungsi Polisi Republik Indonesia dalam Sistem Ketatanegaraan (berdasarkan UUD 1945). Bandung: Cv. Utomo.

Wirjono P. 1986. Asas-asas Hukum Pidana di Indonesia. Bandung :Eresco. 